\title{
Prolonged Unconsciousness Following Severe COVID-19
}

Wilson F. Abdo, MD, PhD, Catharina I. Broerse, MD, Bart P. Grady, MD, PhD, Agnes A.A.C.M. Wertenbroek, MD, Onno Vijlbrief, MD, Marc P. Buise, MD, PhD, Menno Beukema, MD, Mark van der Kuil, MD,

Anil M. Tuladhar, MD, PhD, Frederick J.A. Meijer, MD, PhD, and Johannes G. van der Hoeven, MD, PhD

Neurology ${ }^{\circledR}$ 2021;96:e1437-e1442. doi:10.1212/WNL.0000000000011355

\section{Abstract}

\section{Objective}

We report a case series of patients with prolonged but reversible unconsciousness after coronavirus disease 2019 (COVID-19)-related severe respiratory failure.

\section{Methods}

A case series of patients who were admitted to the intensive care unit due to COVID-19-related acute respiratory failure is described.

\section{Results}

After cessation of sedatives, the described cases all showed a prolonged comatose state. Diagnostic neurologic workup did not show signs of devastating brain injury. The clinical pattern of awakening started with early eye opening without obeying commands and persistent flaccid weakness in all cases. Time between cessation of sedatives to the first moment of being fully responsive with obeying commands ranged from 8 to 31 days.

\section{Conclusion}

Prolonged unconsciousness in patients with severe respiratory failure due to COVID-19 can be fully reversible, warranting a cautious approach for prognostication based on a prolonged state of unconsciousness.

\author{
Correspondence \\ Dr. Abdo \\ f.abdo@radboudumc.nl
}

\section{MORE ONLINE}

COVID-19 Resources

For the latest articles, invited commentaries, and blogs from physicians around the world

NPub.org/COVID19

From the Departments of Intensive Care (W.F.A., J.G.v.d.H.), Neurology (C.I.B., A.M.T.), and Radiology (F.J.A.M.), Radboud University Medical Center, Nijmegen; Departments of Intensive Care (B.P.G.), Neurology (A.A.A.C.M.W.), and Radiology (O.V.), Ziekenhuisgroep Twente, Almelo; Department of Intensive Care (M.P.B.), Catharina Hospital, Eindhoven; Department of Intensive Care (M.B.), Streekziekenhuis Winterswijk; and Department of Intensive Care (M.v.d.K.), Bernhoven Hospital, Uden, the Netherlands

Go to Neurology.org/N for full disclosures. Funding information and disclosures deemed relevant by the authors, if any, are provided at the end of the article. 


\section{Glossary}

COVID-19 = coronavirus disease 2019; ICU = intensive care unit.

In patients with coronavirus disease 2019 (COVID-19) who are admitted to the intensive care unit (ICU) for respiratory distress, an encephalopathy, most notably in the form of delirium, occurs in up to $84 \% .{ }^{1}$ Brain MRI studies in patients in the ICU with COVID-19, including those with prolonged comatose state, reported varying degrees of MRI abnormalities, although few to no details were reported on the clinical picture, course, and prognosis of prolonged unconsciousness in such patients. ${ }^{2}$ Here, we report a case series of patients with COVID-19 admitted to the ICU for respiratory failure who, after cessation of sedatives, remained unconscious for longer than expected periods. We describe how the protracted recovery of unconsciousness followed a similar clinical sequence. Because the world is still dealing with this spreading pandemic, this finding has important implications for the consulting neurologists trying to evaluate and prognosticate patients with COVID-19 with unconsciousness after prolonged periods of mechanical ventilation in the ICU.

\section{Methods}

This is a multicenter case series of patients with severe respiratory failure due to COVID-19 with prolonged unconsciousness after cessation of sedatives. The case of 1 patient is provided, and characteristics of 6 cases with a similar clinical pattern are summarized in table 1 and supplementary table e-1 (available on Dryad, doi.org/10.5061/dryad.866tlglpb).

\section{Standard Protocol Approvals, Registrations, and Patient Consents}

Informed consent was obtained from the patient described in detail.

\section{Data Availability}

Additional anonymized data not available within the article or supplementary material are available to qualified researchers on reasonable request.

\section{Patient 1}

A 41-year-old woman with a medical history of diabetes mellitus, hypothyroidism, and severe obesity (body mass index $43.5 \mathrm{~kg} / \mathrm{m}^{2}$ ) presented to the emergency department with a 3-day history of respiratory symptoms and bilateral infiltrates on her chest $\mathrm{x}$-ray. She tested positive on the oropharyngeal swab test for severe acute respiratory syndrome coronavirus 2. She was admitted to the hospital for oxygen therapy. Two days later, she was transferred to the ICU due to worsening of respiratory status and was intubated the same day. She developed an acute kidney injury necessitating dialysis from day 3 until ICU day 28. She was ventilated in the prone position for the first 7 ICU days and subsequently in the supine position.
She had been on high-dose sedatives since intubation. The sedative midazolam was stopped on ICU day 10 , and the sedative propofol was stopped on ICU day 14. She started opening her eyes to stimuli without other motor reactions 2 days later and did not show any signs of a higher level of consciousness (did not follow objects or persons with her eyes and did not obey commands). She subsequently developed several episodes of high fever with constantly negative blood and sputum cultures with improving infection parameters (Creactive protein, ferritin, procalcitonin, cell counts) and was treated with antibiotics. Because her consciousness level did not improve beyond opening of her eyes, the concentrations of midazolam and its metabolites were measured and were undetectable in blood on ICU day 18. She had been on thyroid supplementary medication during her entire ICU stay, and free thyroxine levels were measured within normal range several times. Ancillary investigations (table 1) showed a severe critical illness polyneuropathy. A brain MRI was subsequently performed on ICU day 26, which showed a diffuse white matter abnormalities (figure). Due to her sustained low level of consciousness and MRI abnormalities, there was doubt about an unfavorable prognosis, and discontinuation of further medical treatment was discussed within the treating team. Follow-up brain MRIs performed on ICU days 33 and 41 showed a slightly improved picture of the diffuse white matter abnormalities, while newly developed restricted diffusion was noted in the basal ganglia (figure). Fourteen days after the sedatives were stopped, she started following people with her eyes for the first time. During the following weeks, her level of consciousness improved, and she eventually started obeying commands adequately with her eyes and facial musculature in combination with a flaccid tetraparesis. She started to move her fingers for the first time on ICU day 63 .

Tables 1 and 2 and supplementary table e- 1 (available on Dryad, doi.org/10.5061/dryad.866tlg1pb) show the characteristics of 6 patients. All were admitted to the ICU for mechanical ventilation and were free of neurologic symptoms at time of ICU admission. Patients were sedated between 14 and 31 days and showed prolonged unconsciousness after the sedatives were stopped. The clinical pattern from unconsciousness to awakening occurred in a similar sequence in all patients. The first feature was opening of the eyes after acoustic or tactile stimuli within 1 to 12 days after sedatives were stopped. This eye opening was not accompanied by any other motor reactions, making any contact, or following objects. Next, 5 to 12 days later, all patients started to follow objects spontaneously with their eyes, which was still not accompanied by obeying commands. At this stage, all patients had a flaccid tetraparesis, areflexia, and no motor reactions to painful stimuli. Subsequently, 1 to 17 days later, patients 
Table 1 Clinical Characteristics of Patients With COVID-19 and Prolonged Unconsciousness

\begin{tabular}{|c|c|c|c|c|c|c|}
\hline $\begin{array}{l}\text { Case } \\
\text { Characteristics }\end{array}$ & $\begin{array}{l}\text { Presented } \\
\text { Case }\end{array}$ & Case 2 & Case 3 & Case 4 & Case 5 & Case 6 \\
\hline Age, y & 41 & 62 & 62 & 47 & 74 & 65 \\
\hline Sex & Female & Male & Male & Female & Female & Male \\
\hline $\begin{array}{l}\text { Time from first } \\
\text { COVID-19 } \\
\text { symptoms to ICU } \\
\text { admission, d }\end{array}$ & 5 & 7 & 13 & 7 & 9 & 7 \\
\hline $\begin{array}{l}\text { Days ventilated } \\
\text { in prone position }\end{array}$ & 7 & 21 & 19 & 8 & 6 & 9 \\
\hline $\begin{array}{l}\text { Days on } \\
\text { ventilator }\end{array}$ & 116 & 55 & 95 & 103 & 33 & 65 \\
\hline $\begin{array}{l}\text { Days on } \\
\text { neuromuscular } \\
\text { paralysis }\end{array}$ & 10 & 14 & 4 & 10 & 4 & 3 \\
\hline $\begin{array}{l}\text { Days on } \\
\text { sedatives }\end{array}$ & 14 & 26 & 31 & 21 & 14 & 15 \\
\hline \multicolumn{7}{|l|}{$\begin{array}{l}\text { Neurologic } \\
\text { features }\end{array}$} \\
\hline \multicolumn{7}{|l|}{$\begin{array}{l}\text { Days between } \\
\text { withdrawal } \\
\text { of sedatives } \\
\text { and }\end{array}$} \\
\hline $\begin{array}{l}\text { Opening of } \\
\text { eyes }\end{array}$ & 2 & 1 & 12 & 5 & 1 & 5 \\
\hline $\begin{array}{l}\text { Spontaneous } \\
\text { following } \\
\text { with eyes }\end{array}$ & 14 & 6 & 14 & 13 & 7 & 12 \\
\hline $\begin{array}{l}\text { First time } \\
\text { obeying } \\
\text { commands }\end{array}$ & 31 & 11 & 18 & 18 & 8 & 14 \\
\hline $\begin{array}{l}\text { Presence of } \\
\text { flaccid paralysis } \\
\text { and areflexia }\end{array}$ & Yes & Yes & Yes & Yes & Yes & Yes \\
\hline $\begin{array}{l}\text { Additional } \\
\text { neurologic } \\
\text { features during } \\
\text { unconsciousness }\end{array}$ & & $\begin{array}{l}\text { Transient anisocoria (1 } \\
\text { episode) }\end{array}$ & $\begin{array}{l}\text { Short tonic-clonic } \\
\text { seizure ( } 1 \text { episode) }\end{array}$ & $\begin{array}{l}\text { Transient } \\
\text { vertical } \\
\text { nystagmus (1 } \\
\text { episode) }\end{array}$ & & \\
\hline Outcome status & $\begin{array}{l}\text { Discharged } \\
\text { from ICU at } \\
\text { day } 116, \text { fully } \\
\text { awake with } \\
\text { slowly } \\
\text { improving } \\
\text { flaccid } \\
\text { tetraparesis }\end{array}$ & $\begin{array}{l}\text { Discharged to high- } \\
\text { care unit after } 58 \mathrm{~d} \text { in } \\
\text { ICU and to } \\
\text { rehabilitation center at } \\
\text { day } 87 \text {, fully awake with } \\
\text { slowly improving } \\
\text { flaccid tetraparesis at } \\
\text { time of ICU discharge }\end{array}$ & $\begin{array}{l}\text { Discharged from ICU } \\
\text { after } 160 \mathrm{~d} \text { and to a } \\
\text { nursing home } 7 \mathrm{~d} \text { later } \\
\text { with severe flaccid } \\
\text { paresis including } \\
\text { dysphagia. Died of } \\
\text { pneumonia } 2 \text { wk after } \\
\text { being discharged to } \\
\text { nursing home }\end{array}$ & $\begin{array}{l}\text { Still at ICU at } \\
\text { day } 150 \text { due to } \\
\text { frequent } \\
\text { suction } \\
\text { support. Off the } \\
\text { ventilator, } \\
\text { persistent } \\
\text { severe } \\
\text { tetraparesis }\end{array}$ & $\begin{array}{l}\text { Discharged to } \\
\text { normal ward after } \\
39 \text { d in ICU, fully } \\
\text { awake with slowly } \\
\text { improving flaccid } \\
\text { tetraparesis at } \\
\text { time of ICU } \\
\text { discharge }\end{array}$ & $\begin{array}{l}\text { Discharged to } \\
\text { normal ward after } \\
77 \text { d in ICU, fully } \\
\text { awake with slowly } \\
\text { improving flaccid } \\
\text { tetraparesis at } \\
\text { time of ICU } \\
\text { discharge }\end{array}$ \\
\hline
\end{tabular}

Abbreviations: COVID-19 = coronavirus disease 2019; ICU = intensive care unit.

started to obey commands for the first time, which always began with facial musculature such as closing and opening of the eyes or mouth. Motor reactions with the limbs occurred in the last phase. All patients had a flaccid paralysis after awakening that remained present for the recorded days in the ICU or resolved only very slowly. In 5 of the 6 patients, a mixed or hypoactive delirium was diagnosed after recovery of the unconsciousness.

\section{Discussion}

In this case series, prolonged level of unconsciousness with full recovery of the unconsciousness in patients with severe COVID19 is shown. The brain imaging abnormalities found in our described case and other patients within our series are in line with recently reported series of brain imaging in patients with COVID-19 and a postmortem neuropathologic analysis, 


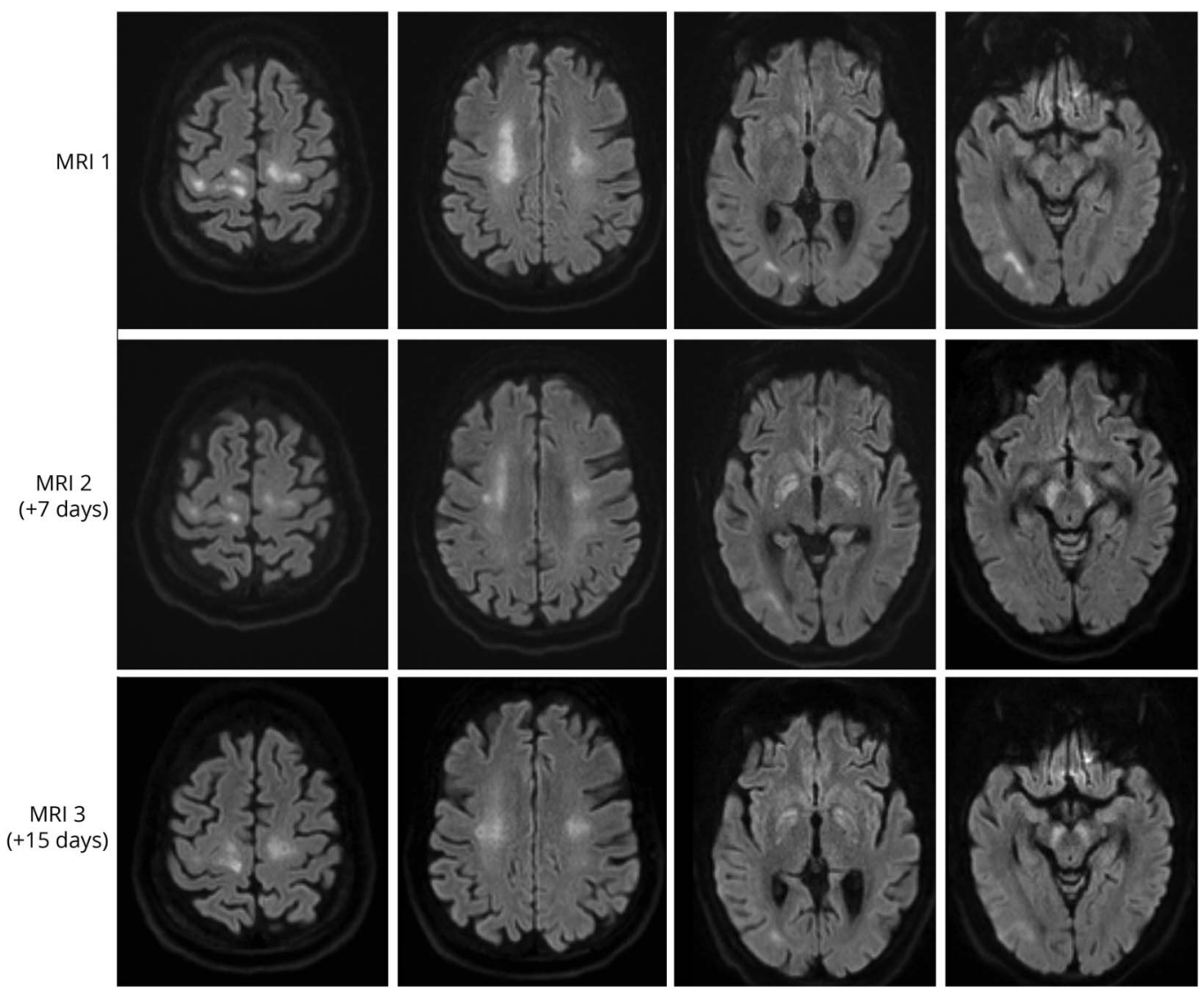

Diffuse leukoencephalopathy with restricted diffusion in the corona radiata and subcortical white matter on the first MRI slightly decreased on follow-up MRIs. Newly developed restricted diffusion of the globus pallidus and substantia nigra was seen on the second and third MRIs. No signs of hemorrhages, territorial infarcts, or microbleeds were seen.

showing microbleeds and white matter abnormalities in varying degrees. $^{2,3}$ Some of these abnormalities have also been reported previously in other critical illnesses, including a prolonged reversible comatose state in a case of sepsis. ${ }^{4-6}$ The main differential diagnosis in our case was a persistent comatose state due to parainfectious autoimmune-mediated encephalitis or critical illness-related encephalopathy. The clinical course in our case series, normal CSF analyses, and spontaneous improvement without any corticosteroids most likely support a critical illness-related encephalopathy, although a clear distinction is difficult to make. A long ICU course in severe COVID-19 is not unusual. Due to the use of sedatives and muscle relaxants during longer periods in patients with COVID-19 admitted to the ICU, such patients often develop a severe form of ICU-acquired weakness. Factors such a long use of sedatives and the presence of severe generalized muscle weakness (present in all our cases) complicate assessment of the level of consciousness.

In all of our patients, a similar clinical pattern was observed during recovery of their unconsciousness. Opening of the eyes occurred in the first week after sedatives were stopped in 5 of the 6 patients without any other motor reactions with generalized flaccid paralysis. This was followed by visual tracking of people within 2 weeks after cessation of sedatives. Obeying commands (mostly through facial musculature) occurred between 8 and 31 days after cessation of sedatives. This pattern of awakening did not fit the regular patterns seen in patients in the ICU in whom eye opening is frequently accompanied or quickly followed by motor reactions to (painful) stimuli and an encephalopathy with an active delirium, as was also shown in the great majority of patients with COVID-19 in the ICU. ${ }^{1}$ Our findings corroborate a recent case report showing intact functional connectivity in the default mode network using fMRI in a patient with prolonged unconsciousness admitted to the ICU for respiratory failure due to COVID-19. ${ }^{7}$ One of the main drawbacks of our study is the selection bias that is inherent to case series. Although the patients recovered from their prolonged unconscious state, it is likely that long-term cognitive or physical deficits remain present, in line with many reports on long-term outcomes in patients with COVID-19.

Neurologists are frequently consulted due to neurologic symptomatology in patients with COVID-19. As our case series shows, it is conceivable that neurologists could be faced with the dilemma to prognosticate on the basis of a prolonged state of unconsciousness, all with the background of a pandemic with the 
Table 2 Ancillary Neurologic Workup

\begin{tabular}{|c|c|c|c|c|c|c|}
\hline & Presented Case & Case 2 & Case 3 & Case 4 & Case 5 & Case 6 \\
\hline $\begin{array}{l}\text { Lumbar } \\
\text { puncture }\end{array}$ & & & NA & & NA & NA \\
\hline $\begin{array}{l}\text { White cell } \\
\text { count, } n / \mu L\end{array}$ & 1 & 2 & & 1 & & \\
\hline $\begin{array}{l}\text { Protein } \\
\text { (normal } \\
\text { range } \\
\text { 197-597), } \\
\text { mg/L }\end{array}$ & 580 & 184 & & 1,017 & & \\
\hline $\begin{array}{l}\text { PCR SARS- } \\
\text { CoV-2 }\end{array}$ & Negative & Negative & & Negative & & \\
\hline $\begin{array}{l}\text { Viral/ } \\
\text { microbial } \\
\text { panel }\end{array}$ & Cultures negative $^{a}$ & $\begin{array}{l}\text { Cultures } \\
\text { negative }^{a}\end{array}$ & & Cultures negative & & \\
\hline Additional & & & & $\begin{array}{l}\text { Anti-ganglioside } \\
\text { antibodies negative }\end{array}$ & & \\
\hline EMG & $\begin{array}{l}\text { Severe axonal } \\
\text { polyneuropathy }\end{array}$ & NA & NA & $\begin{array}{l}\text { Severe } \\
\text { polyneuropathy; no } \\
\text { sensory/motor action } \\
\text { potentials measurable }\end{array}$ & NA & NA \\
\hline Brain CT & Unremarkable & $\begin{array}{l}\text { Small } \\
\text { intraventricular } \\
\text { bleeding }\end{array}$ & Unremarkable & Unremarkable & Unremarkable & Unremarkable \\
\hline Routine EEG & $\begin{array}{l}\text { Generalized } \\
\text { slowing, } \\
\text { background } \\
\text { reactivity present, } \\
\text { no epileptiform } \\
\text { activity }\end{array}$ & NA & $\begin{array}{l}\text { ( } 2 \text { times) Generalized } \\
\text { slowing, background } \\
\text { reactivity absent, no } \\
\text { epileptiform activity }\end{array}$ & NA & NA & NA \\
\hline Brain MRI & & & & NA & NA & \\
\hline Microbleeds & - & + & - & & & + \\
\hline $\begin{array}{l}\text { Leukoence } \\
\text { phalopathy }\end{array}$ & + & + & + & & & - \\
\hline Infarcts & - & - & - & & & - \\
\hline
\end{tabular}

Abbreviations: NA = not available; SARS-CoV-2 = severe acute respiratory syndrome coronavirus 2.

${ }^{a}$ Apart from normal cultures, additional molecular panel on CSF included adenovirus/enterovirus/herpes simplex virus 1 and 2, Hemophilus influenzae, Mycoplasma pneumoniae, Neisseria meningitidis, Human parechovirus, Streptococcus agalactiae, Streptococcus pneumoniae, and varicella-zoster virus.

need for ICU capacity exceeding available resources. It is important to take into account the possible reversibility of prolonged unconsciousness in patients with COVID-19 admitted to the ICU, which warrants watchful waiting in such cases.

\section{Study Funding}

There was no funding agency/sponsor involved.

\section{Disclosure}

All authors report no conflicts of interest or relevant financial relationships related to this manuscript. Go to Neurology. org/ $\mathrm{N}$ for full disclosures.

\section{Publication History}

Received by Neurology August 14, 2020. Accepted in final form November 23, 2020.

\section{Appendix Authors}

\begin{tabular}{|c|c|c|}
\hline Name & Location & Contribution \\
\hline $\begin{array}{l}\text { Wilson F. } \\
\text { Abdo, MD, } \\
\text { PhD }\end{array}$ & $\begin{array}{l}\text { Department of Intensive } \\
\text { Care, Radboud University } \\
\text { Medical Center, } \\
\text { Nijmegen, the } \\
\text { Netherlands }\end{array}$ & $\begin{array}{l}\text { Conception and design of } \\
\text { the study and drafted the } \\
\text { first version of the } \\
\text { manuscript; acquisition } \\
\text { and analysis of the data; } \\
\text { provided input to } \\
\text { the draft manuscript }\end{array}$ \\
\hline $\begin{array}{l}\text { Catharina I. } \\
\text { Broerse, MD }\end{array}$ & $\begin{array}{l}\text { Department of } \\
\text { Neurology, Radboud } \\
\text { University Medical Center, } \\
\text { Nijmegen, the } \\
\text { Netherlands }\end{array}$ & $\begin{array}{l}\text { Conception and design } \\
\text { of the study and } \\
\text { drafted the first version } \\
\text { of the manuscript; } \\
\text { acquisition and analysis } \\
\text { of the data; provided } \\
\text { input to the draft } \\
\text { manuscript }\end{array}$ \\
\hline
\end{tabular}

Continued 
Appendix (continued)

\begin{tabular}{|c|c|c|}
\hline Name & Location & Contribution \\
\hline $\begin{array}{l}\text { Bart P. Grady, } \\
\text { MD, PhD }\end{array}$ & $\begin{array}{l}\text { Department of Intensive } \\
\text { Care, Ziekenhuisgroep } \\
\text { Twente, Almelo, the } \\
\text { Netherlands }\end{array}$ & $\begin{array}{l}\text { Acquisition and analysis } \\
\text { of the data; provided } \\
\text { input to the draft } \\
\text { manuscript }\end{array}$ \\
\hline $\begin{array}{l}\text { Agnes } \\
\text { A.A.C.M. } \\
\text { Wertenbroek, } \\
\text { MD }\end{array}$ & $\begin{array}{l}\text { Department of } \\
\text { Neurology, } \\
\text { Ziekenhuisgroep Twente, } \\
\text { Almelo, the Netherlands }\end{array}$ & $\begin{array}{l}\text { Acquisition and analysis } \\
\text { of the data; provided } \\
\text { input to the draft } \\
\text { manuscript }\end{array}$ \\
\hline $\begin{array}{l}\text { Onno Vijlbrief, } \\
\text { MD }\end{array}$ & $\begin{array}{l}\text { Department of Radiology, } \\
\text { Ziekenhuisgroep Twente, } \\
\text { Almelo, The Netherlands }\end{array}$ & $\begin{array}{l}\text { Acquisition and analysis of } \\
\text { the data; provided input to } \\
\text { the draft manuscript }\end{array}$ \\
\hline $\begin{array}{l}\text { Marc P. Buise, } \\
\text { MD, PhD }\end{array}$ & $\begin{array}{l}\text { Department of Intensive } \\
\text { Care, Catharina Hospital, } \\
\text { Eindhoven, the } \\
\text { Netherlands }\end{array}$ & $\begin{array}{l}\text { Acquisition and analysis } \\
\text { of the data; provided } \\
\text { input to the draft } \\
\text { manuscript }\end{array}$ \\
\hline $\begin{array}{l}\text { Menno } \\
\text { Beukema, MD }\end{array}$ & $\begin{array}{l}\text { Department of Intensive } \\
\text { Care, Streekziekenhuis } \\
\text { Winterswijk, the } \\
\text { Netherlands }\end{array}$ & $\begin{array}{l}\text { Acquisition and analysis } \\
\text { of the data; provided } \\
\text { input to the draft } \\
\text { manuscript }\end{array}$ \\
\hline $\begin{array}{l}\text { Mark van der } \\
\text { Kuil, MD }\end{array}$ & $\begin{array}{l}\text { Department of Intensive } \\
\text { Care, Bernhoven Hospital, } \\
\text { Uden, the Netherlands }\end{array}$ & $\begin{array}{l}\text { Acquisition and analysis of } \\
\text { the data; provided input to } \\
\text { the draft manuscript }\end{array}$ \\
\hline $\begin{array}{l}\text { Anil M. } \\
\text { Tuladhar, MD, } \\
\text { PhD }\end{array}$ & $\begin{array}{l}\text { Department of } \\
\text { Neurology, Radboud } \\
\text { University Medical Center, } \\
\text { Nijmegen, the } \\
\text { Netherlands }\end{array}$ & $\begin{array}{l}\text { Conception and design of } \\
\text { the study and drafted the } \\
\text { first version of the } \\
\text { manuscript; acquisition } \\
\text { and analysis of the data; } \\
\text { provided input to the draft } \\
\text { manuscript }\end{array}$ \\
\hline
\end{tabular}

Appendix (continued)

\begin{tabular}{|c|c|c|}
\hline Name & Location & Contribution \\
\hline $\begin{array}{l}\text { Frederick J.A. } \\
\text { Meijer, MD, } \\
\text { PhD }\end{array}$ & $\begin{array}{l}\text { Department of Radiology, } \\
\text { Radboud University } \\
\text { Medical Center, } \\
\text { Nijmegen, the } \\
\text { Netherlands }\end{array}$ & $\begin{array}{l}\text { Conception and design of } \\
\text { the study and drafted the } \\
\text { first version of the } \\
\text { manuscript; acquisition } \\
\text { and analysis of the data; } \\
\text { provided input to the } \\
\text { draft manuscript }\end{array}$ \\
\hline $\begin{array}{l}\text { Johannes G. } \\
\text { van der } \\
\text { Hoeven, MD, } \\
\text { PhD }\end{array}$ & $\begin{array}{l}\text { Department of Intensive } \\
\text { Care, Radboud University } \\
\text { Medical Center, } \\
\text { Nijmegen, the } \\
\text { Netherlands }\end{array}$ & $\begin{array}{l}\text { Conception and design } \\
\text { of the study and drafted } \\
\text { the first version of the } \\
\text { manuscript; } \\
\text { acquisition and analysis } \\
\text { of the data; provided } \\
\text { input to the draft } \\
\text { manuscript }\end{array}$ \\
\hline
\end{tabular}

\section{References}

1. Helms J, Kremer S, Merdji H, et al. Delirium and encephalopathy in severe COVID19: a cohort analysis of ICU patients. Crit Care 2020;24:491.

2. Radmanesh A, Derman A, Lui YW, et al. COVID-19-associated diffuse leukoencephalopathy and microhemorrhages. Radiology 2020;297:E223-E227.

3. Reichard RR, Kashani KB, Boire NA, Constantopulos E, Guo Y, Lucchinetti CF Neuropathology of COVID-19: a spectrum of vascular and acute disseminated encephalomyelitis (ADEM)-like pathology. Acta Neuropathol 2020;140:1-6.

4. Sharhar T, Annane D, de la Graindmaison GL, Brouland JP, Hopkinson NS, Françoise G. The neuropathology of septic shock. Brain Pathol 2004;14:21-33.

5. Breit H, Jhaveri M, Sayona J. Concomitant delayed posthypoxic leukoencephalopathy and critical illness microbleeds. Neurol Clin Pract 2018;8:31-33.

6. Luiste MJ, Van Ash CJ, Klijn CJ. Deep coma and diffuse white matter abnormalities caused by sepsis-associated encephalopathy. Lancet 2013;381;2222.

7. Fisher D, Threlkeld ZD, Bodien YG, et al. Intact brain network function in an unresponsive patient with COVID-19. Ann Neurol 2020;88:851-854. 


\section{Neurology}

\section{Prolonged Unconsciousness Following Severe COVID-19 \\ Wilson F. Abdo, Catharina I. Broerse, Bart P. Grady, et al.}

Neurology 2021;96; e1437-e1442 Published Online before print December 21, 2020

DOI 10.1212/WNL.0000000000011355

This information is current as of December 21, 2020

Updated Information \&

Services

References

Citations

Subspecialty Collections

Permissions \& Licensing

Reprints including high resolution figures, can be found at: http://n.neurology.org/content/96/10/e1437.full

This article cites 7 articles, 0 of which you can access for free at: http://n.neurology.org/content/96/10/e1437.full\#ref-list-1

This article has been cited by 4 HighWire-hosted articles: http://n.neurology.org/content/96/10/e1437.full\#\#otherarticles

This article, along with others on similar topics, appears in the following collection(s):

All Clinical Neurology

http://n.neurology.org/cgi/collection/all_clinical_neurology

\section{Coma}

http://n.neurology.org/cgi/collection/coma

COVID-19

http://n.neurology.org/cgi/collection/covid_19

Information about reproducing this article in parts (figures,tables) or in its entirety can be found online at:

http://www.neurology.org/about/about_the_journal\#permissions

Information about ordering reprints can be found online:

http://n.neurology.org/subscribers/advertise

Neurology ${ }^{\circledR}$ is the official journal of the American Academy of Neurology. Published continuously since 1951, it is now a weekly with 48 issues per year. Copyright Copyright ( 2020 The Author(s). Published by Wolters Kluwer Health, Inc. on behalf of the American Academy of Neurology.. All rights reserved. Print ISSN: 0028-3878. Online ISSN: 1526-632X.

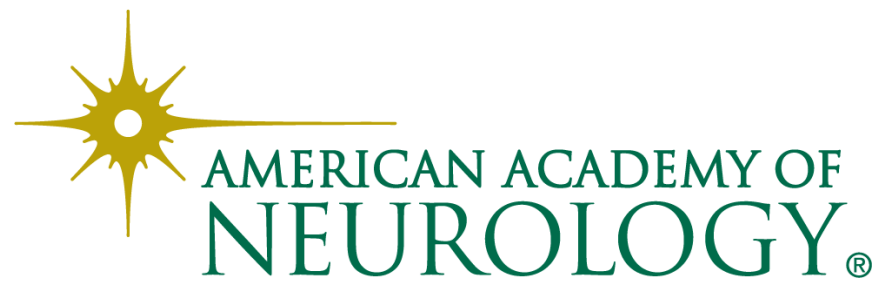

